DOI: $10.22363 / 2312-8313-2017-4-2-180-201$

\title{
REGIONAL DISPARITIES IN ECONOMIC DEVELOPMENT: LESSONS LEARNED FROM THE UNITED STATES OF AMERICA
}

\author{
D. Schultz \\ Hamline University \\ St. Paul, Minnesota, USA, 55105
}

\begin{abstract}
Economic development is not geo-politically uniform. There is a geographic component that leaves some regions within the world or some parts of a country, including the Russian Federation, more economically developed that others. This article examines uneven economic development in the USA as a case study. Specifically, this article defines what is meant by uneven development, as well as documents the pattern of uneven development in the United States. The article also looks at the causes and consequences of uneven development and discusses some possible remedies. Overall the conclusion is that the USA experiences a significant geographic component to its economic development and it is not clear that the policies it has undertaken, if at all, have been successful to abating, slowing down, or reversing uneven development.
\end{abstract}

Key words: uneven economic development; United States; spatial inequality; poverty; income inequality

\section{Introduction}

Economic development is not geo-politically uniform. There is a geographic component that leaves some regions within the world more economically developed that others. World systems analysis that emphasizes core-periphery development since the sixteenth century has documented this reality $[9,54]$. Some nation-states can extract through colonies or trade regional if not outright dominate positions in the world. At one time this regional disparity was also known as the North-South divide, or during the Cold War it referred to the First (and Second) versus Third world economies.

But there also a geographic or spatial pattern to economic development within countries. China, for example, displays a significant disparity in income between many of its coastal areas and its western provinces, for example [4]. The same is true for the Russian Federation as well as for many other states of the world. 
Often that geographic disparity is split between richer urban versus rural areas, with the former benefitting from better industrialization or now post-industrial high technology service economies [47].

At one time modernization theory described uneven development as a sign or indication of a backward economy. Yet that it not the case, as even advanced capitalist economies such as the United States of America face this problem.

This article examines uneven economic development in the USA. Specifically, it defines what is meant by uneven development, as well as documents the pattern of uneven development in the USA. The article also looks at causes and consequences of uneven economic development and discusses some possible remedies. Overall the conclusion is that the USA experiences a significant geographic component to its economic development and it is not clear that the policies it has undertaken, if at all, have been successful to abating, slowing down, or reversing uneven development. The United States thus serves as a case study for the Russian Federation and other countries in terms of the challenges in addressing uneven economic development.

\section{Defining Uneven Economic Development}

There is no one set definition or measurement of uneven economic development. Also, known or referred to a spatial inequality, Kim describes it as geographic or regional differences in health, education, and poverty [22, 23, 25, 25, 26, 27 28]. $\mathrm{Wu}$ and Gopinath contend it is regional differences as determined by standard measures such as income and employment [59]. Harris defines it as "persistent differences in levels and rates of economic development between different sectors of the economy" [15] Lobao specifies spatial inequality as "place stratification or inequality within and between territorial units" [38].

Kyrylych [34] argues that uneven economic development is a consequence of capitalist development. He states that capitalism has a tendency to focus growth and investment in certain regions. The advantages of these regions can be defined with the help of specific set of factors: geographical location, resource potential and the potential of labour force, availability of capital and so on. Concentration of growth in a certain region leads to increased investment, labour and resources from the surrounding regions, which subsequently act as a secondary supply of resources and labour force in the area of economic prosperity.

Central to these definitions is a contention or recognition that within a region, whether it be nationally, domestically, or even within subregions of a country, economic development is not geographically or spatially uniform. Instead it clumps or bunches together in groups or clusters. These disparities may play out in terms of urban versus rural areas for example, or within parts of urban areas [57, 58]. The point is that some areas exhibit more advanced or concentrated economic development than others. 
This concentration or clumping of economic development leads to two important questions: How is spatial inequality measured and what are the causes of it? Both questions are in dispute.

One typical measure of uneven development is the GINI Coefficient. GINI is a standard measure of economic inequality used widely by economists and entities such as the World Bank and the Organization of Economic Cooperation and Development (OECD). GINI is a statistical measure of the dispersion of income. Calculation of GINI usefully describes one important measure but certainly income is not a sole determinant regarding uneven development. Additionally, while one can compare GINI coefficients across units of analysis such as regions, in and of itself it is not a spatial measure. Instead, there are several possible variables that could be measures of spatial inequality. For example, in addition to income dispersion, poverty rates, median income, or per capita GDP would be measures of uneven economic development. Other perhaps indirect but still valid measures could consider health measures such as life expectancy, percentage of the population with health insurance, per capita daily calorie count, or even some measure of new industrial investment or individual consumption, held constant on a per capita basis that would perhaps serve as evidence of uneven development. The measure would have to be comparative, examining the differences in any of these variables along some scale in terms of how they vary from a median in terms of dispersal.

The second question is why and what causes spatial inequalities? $\mathrm{Wu}$ and Gopiniath argue that "from the perspective of theory, spatial inequality is fundamentally determined by the location decisions of firms and households" [59]. By that, both make decisions regarding where they wish to invest or locate. What factors affect those decisions? Classical economic theory indicates that three factors, natural amenities, infrastructure, and remoteness all affect economic development [33]. Natural amenities are factors such as proximity to water supply, natural resources, hospitable or appropriate weather. Central place or other regional theories of growth indicate that natural amenities might be related to simply natural factors such as a city developing on a navigable river, or at a portage point, or at an intersection of some other geographical features [39]. If energy costs are an issue, for example, warmer climates that do not require a much heat would have an advantage over colder climate areas [30, 31].

A second factor is remoteness. All things being equal, a place considered more remote or difficult to reach will be less likely to be developed as those which are more proximate. Central place theory contends that businesses are more likely to develop in places that are more centrally to consumers or markets. Other studies point to how business investment location decisions are influenced by proximity to markets and suppliers. If transportation costs are an issue, being located closer to either of these will be a factor affecting investment. Michael Porter has additionally trumpeted a cluster theory, contending that like-minded businesses will develop 
near one another so that they can draw upon similar workforce skill sets [48, 49]. In fact, many theories of economic location contend that the number one factor affecting business decisions to locate and invest are related to workforce skills can the company find suitably skilled employees at an affordable wage. Remote may also refer to not simply distance but the difficulty of getting to a location. How difficult or arduous is it to reach a place to do business? Conversely, how difficult would it be for consumers or suppliers to reach a firm? On balance, the more remote a location the less likely it is to benefit from economic investments and face spatial inequality.

The third factor affecting uneven development is infrastructure. Infrastructure backs to the days on Adam Smith and the Wealth of Nations referred to the building of roads, canals, and bridges. Increasing and improving transportation would reduce problems in terms of proximity, socializing these costs in ways that would relieve the burden from a business (or externalities or transaction costs) to have to make outlays for them. But infrastructure investment is even more broad than that now. Education or work force training is one modern example. Government programs that subsidize these costs might make an area more enticing for business investment than it was before. Other infrastructure investments could include building airports, railroads, telecommunications and internet, and even such non-economic things such as quality of life amenities such as support for art, sport, and cultural programs. The goal of infrastructure investment is to offset both natural amenities and remoteness as variables affecting uneven investment or development.

The core argument with these three factors (or at least the first two) is that in a free market system businesses and consumers act rationally to make location decisions based on costs or returns on investment. Some areas receive more investment because they are economically more efficient, productive, or cost efficient than others. Thus, along with income or wealth inequality, spatial inequality is one of the externalities of capitalism which is more concerned with efficiency as opposed to equity or equality. But critics of capitalism have also argued that other factors come to play that augment or exacerbate market forces. For example, historic trade routes or patterns might produce uneven development. Wallerstein [54], Plant [47], and Harvey [16] all see within capitalism the power of core or dominant players to use their positions and power to exploit peripheral or colonial areas. Piketty argues that inequality (including spatially) is a product of $\alpha=\operatorname{rx} \beta$, where $\alpha$ is the share of capital income and it is equal to the "product of the return on capital and the capital/ income ratio" [46].

Racism is also offered as reasons affecting uneven development or choices about where to invest, and still others have contended that globalization can impact development. Hanley notes that regional differences in economic inequality between the south and southwest US compared to the Northeast and Midwest is a consequence of businesses seeking to escape labor unions [14]. Tomaskovic- 
Devey and Roscigno note the North-South regional differences in poverty and economic development have a racial dimension in that areas which appear to be poorer or less developed have greater concentrations of the population which are AfricanAmerican [53]. Lichtner and Johnson [36], Lichtner, Parisi, and Taquino [37], Kucheva [32], Wilson [57, 58], and Jargowsky [21] have documented how concentrated poverty is spatially situated in rural, urban, and now inner ring suburbs, with this poverty interconnected with race.

Institutional or neo-institutional analysis posits that governmental agencies or structures can impact development. For example, a choice of governmental structure such as a federal system breaking up an area into regions may produce uneven development because of fragmented governmental policies or costs of working with governments. Tiebout has contended that within metropolitan areas, local governments compete for businesses and residents by offering a varying package of local services and taxes. In theory, this competition yields the most efficient sorting of investment location decisions, but there is no guarantee that it will be uniform. But an institutional analysis indicates also that governments can affect location decisions via a host of public policy initiatives ranging from infrastructure investments and tax subsidies. Even factors such as corruption or clean government can be a factor, with generally the best studies indicating that economically better performing regions have less political corruption than others

Finally, even if capitalism produces unequal development, economists such as Kuznets argue that investment and development is initially a large "U" curve. By that, initial development may start off uneven but over time those differences are ameliorated and leveled as underdevelopment areas catch up. Classical theories of international economic development made these arguments that spatial theories of economic development are a product of underdevelopment or have a temporal component. Specifically, given enough time development will even out.

The last issue when it comes to understanding or studying uneven development is the unit of analysis. One unit of analysis would perhaps in the United States look at develop across regions such as the different states, or even broader regions such as northern, Midwestern, or southern states. This might be a macro analysis. A meso analysis might bring the examination down to the level of counties or cities, with a micro analysis perhaps going so far as to looking at rural, urban, versus suburban, or even down to the level of US Census track. Other possibilities might include what the US Census Bureau refers to as Metropolitan Statistical Areas (MSAs). SMSAs are integrated geo-political areas with at least one city with a population of 50,000 individuals. Currently there are 382 SMAs in the United States. Often economic analysis is done drawing upon comparisons of the SMAs across one another or looking at regions within them.

Overall, there is no consensus regarding the correct unit of analysis to study uneven economic development in the United States. Varying levels of analysis along with often overlapping criteria are employed to study this phenomenon. 


\section{Uneven Economic Development in the USA}

The US like most countries in the word experiences uneven economic development. This uneven development can be depicted across several units of analysis, measuring varying variables to describe or depict it.

Consider first a series of US Census Bureau maps that depict four measures of uneven economic development. The first map examines the changes in population density in the United States from 1930 to 2000. Note especially a pattern along the central part of the US from Texas north to North Dakota. This is the area that used to be known as the high planes. It is mostly agricultural and it has lost a significant percentage of its population. The same is true for rural areas of the South from Georgia west to Oklahoma. The second map looks at median household income in 2014, finding, at least in the south, a visual overlay in terms of population loss and it. The third map depicts poverty rates, again demonstrating some overlay with population loss and income. The fourth map looks at recent unemployment rates across counties. Overall, the four maps clearly reveal distinct patterns in terms of development. Now contrast this last map on unemployment rates to a fifth map which looks at how unemployment rates in MSAs vary from the United States mean. We would find in looking at this fifth map that some MSAs having higher versus lower unemployment rates, indicating varying levels of economic development that spatially vary across major urban areas.

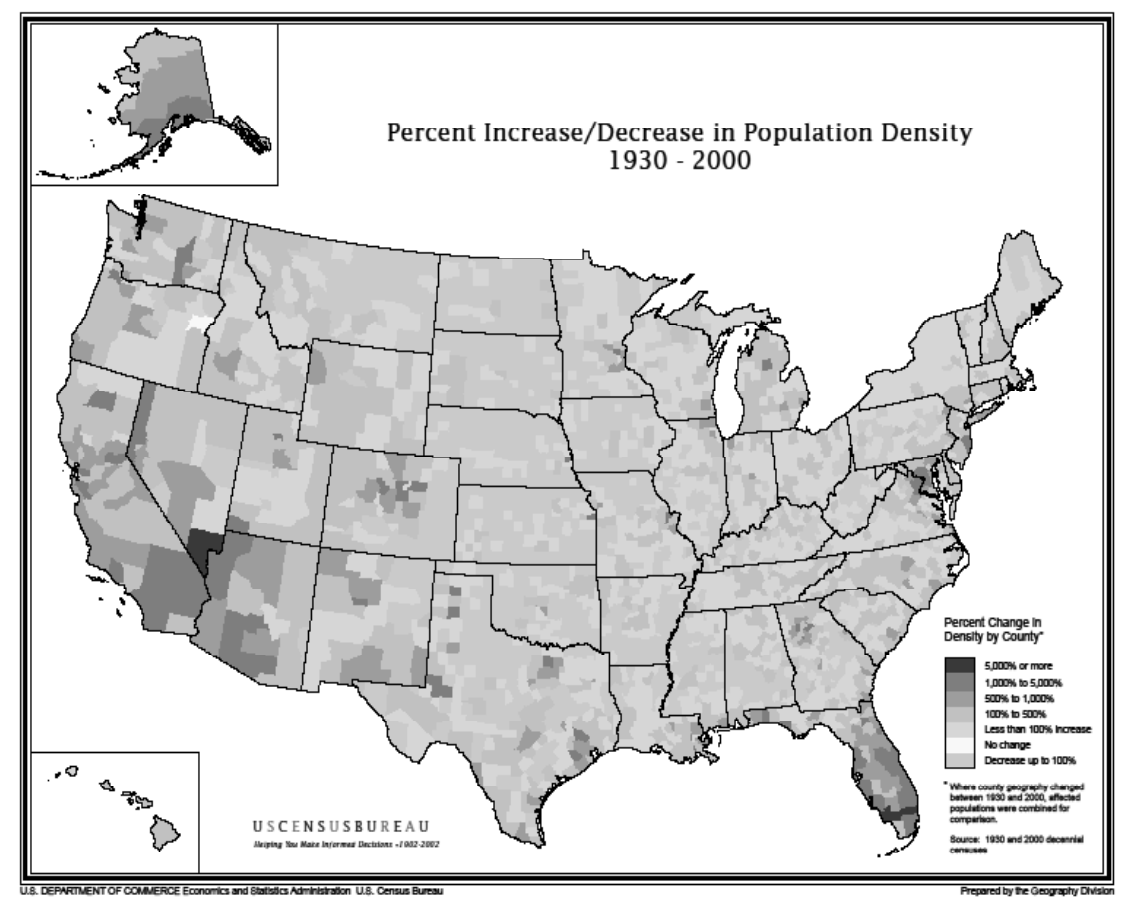

Figure 1. Percent increase/decrease in population density, 1930-2000 


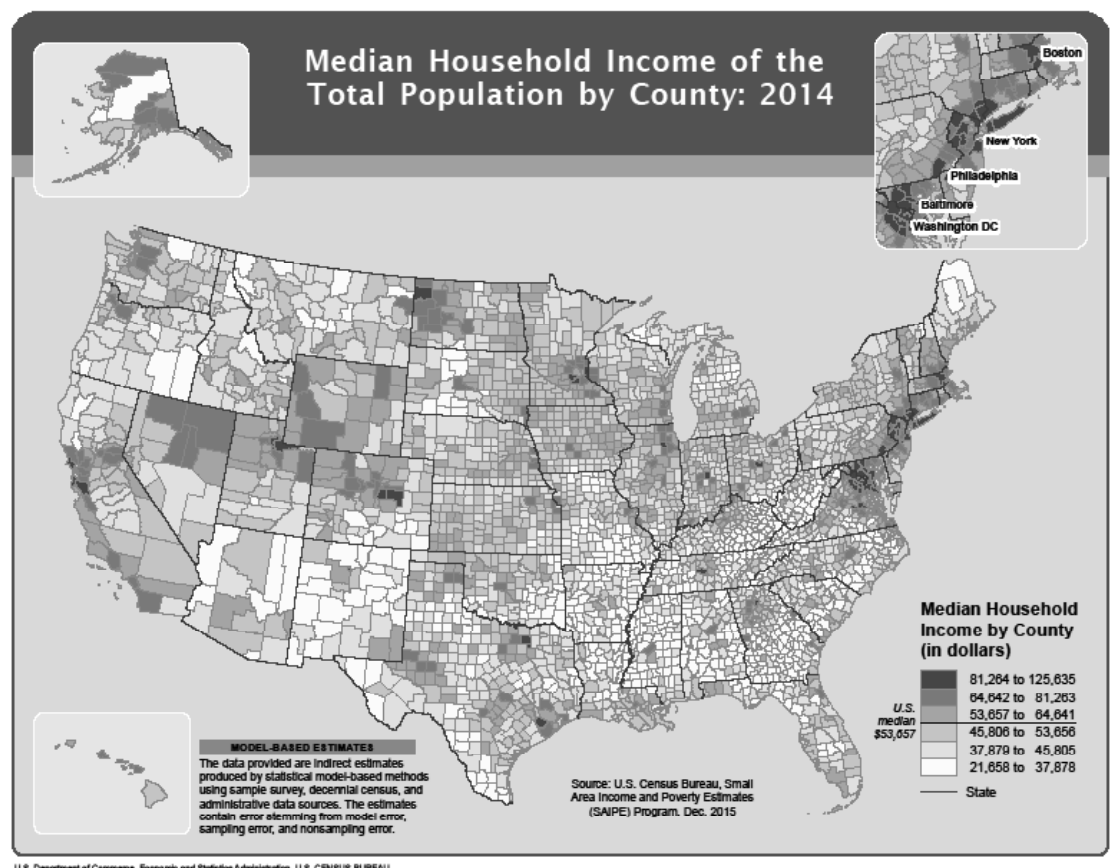

Figure 2. Median household income of the total population by county: 2014

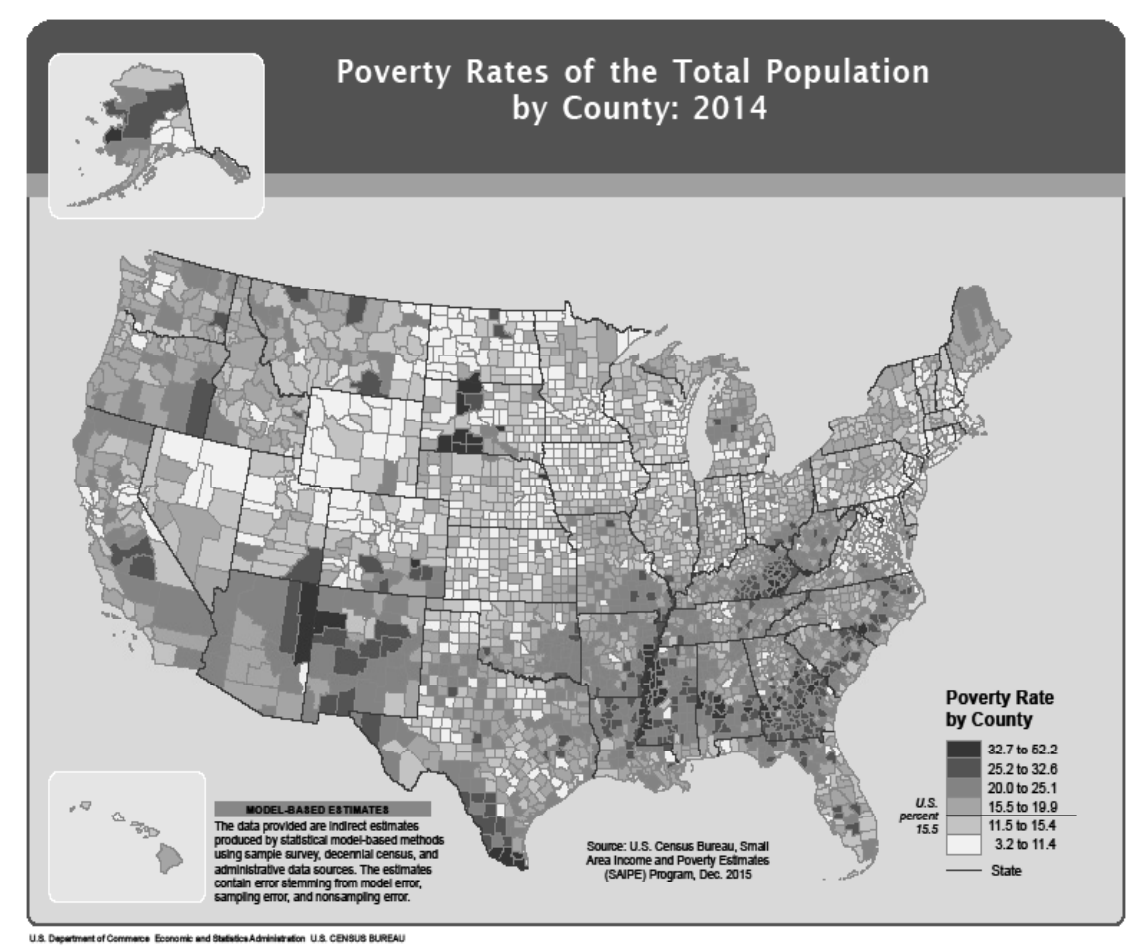

Figure 3. Poverty rates of the total population by county: 2014 


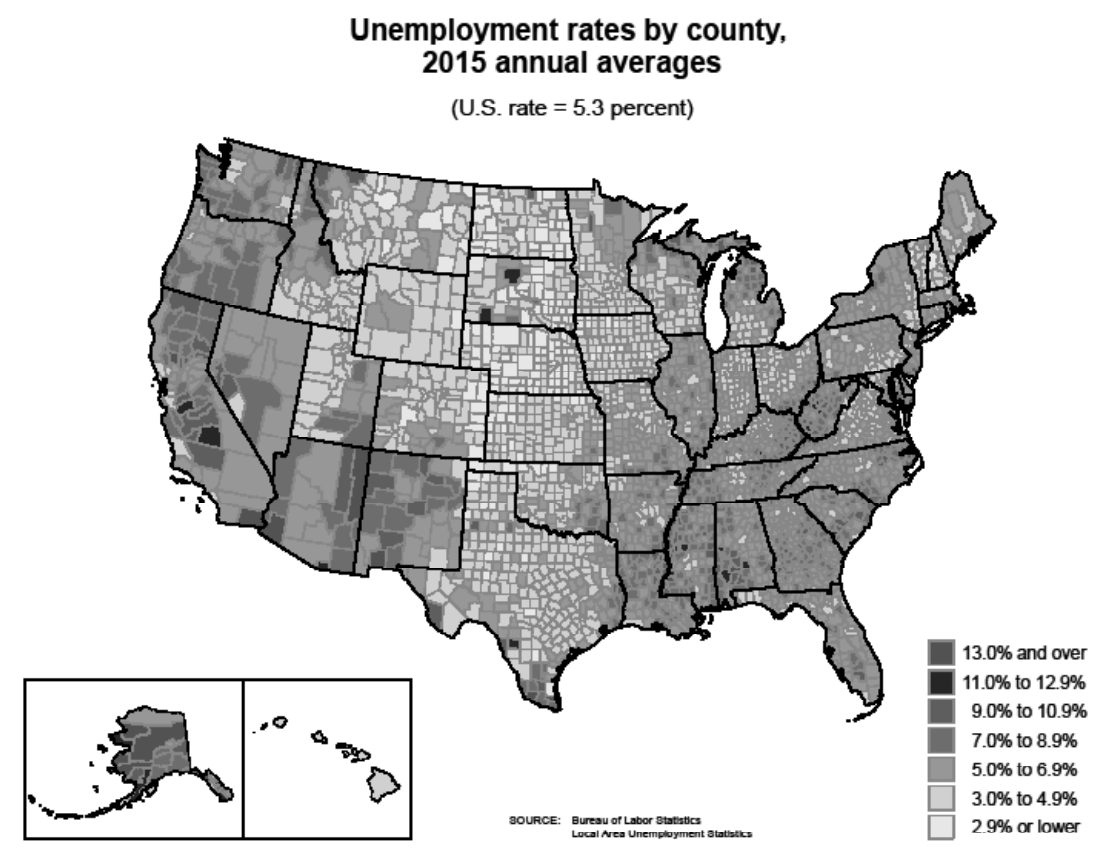

Figure 4. Unemployment rates by county, 2015 annual averages

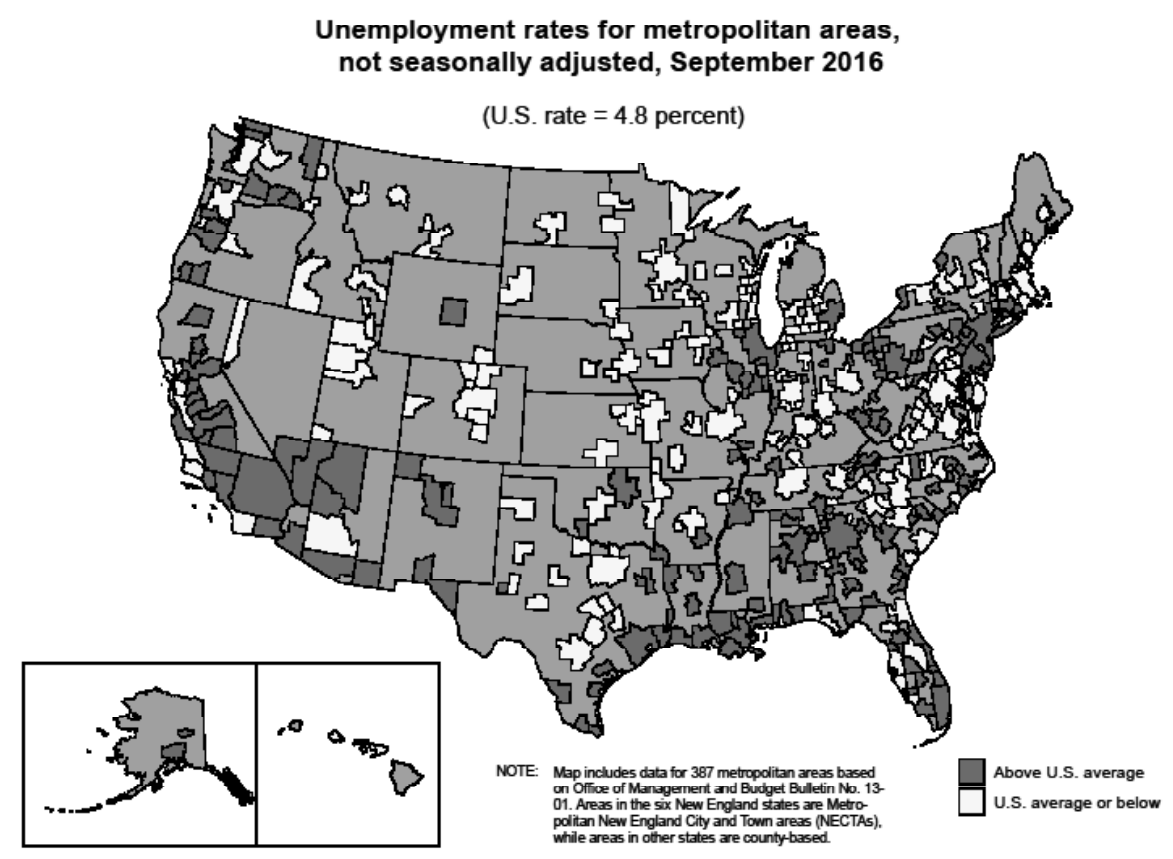

Figure 5. Unemployment rates for metropolitan areas, not seasonally adjusted, September 2016 
Another way to examine uneven economic development is by region or state. The US Census bureau groups the 50 states into four regions: Northeast, Midwest, South, and West. Consider just poverty for example, and drawing upon 2014 data, the rates for each of the regions is $12.6 \%, 13.7 \%, 17.2 \%$, and $14.5 \%$, respectively. At the state level, New Hampshire has the lowest poverty rate at $9.2 \%$, whereas Mississippi is the highest at $21.9 \%$. Mississippi also has the lowest median family income at $\$ 39,738$, whereas Maryland has the highest at \$ 73,851. Again, these statistics reveal regional and state-based differences in inequality.

Now consider another way to think about uneven economic development. In this case, level of educational achievement. Here one is looking to see if there is any connection between level of educational achievement and poverty. The hypothesis would be that in general the better educated individuals are the less likely they would be in poverty. Looking at a correlation between the two would test whether providing more education or perhaps workforce training would facilitate investment in an area (because there are better trained workers). The US Census Bureau gathers down to the county level educational statistics asking individuals whether their highest educational achievement was a high school degree, some college, or receiving a bachelor's degree or something beyond that. One can correlate these statistics at several levels of analysis. Here, correlations were calculated at the state and county level.

At the state level, there is a 0.208 correlation between the percentage of the population receiving a high school degree (as their highest educational achievement) and poverty rates. It changes to -0.145 for some college, and to -0.468 for a BA or beyond. Clearly as a percentage of a state's population becomes better educated the poverty rate decreases, suggesting that more education or training more help abate or address one measure of spatial inequality. When the same correlations are performed computing county level data, the results ae $0.180,-0.364$, and -0.169 . There is still a correlation between educational achievement and poverty, with the latter generally declining as a percentage of the population becomes better educated, but unlike at the state level where graduating from a four-year school or beyond had the most robust results, at the county level it was some college that was most robust.

Overall, whatever unit of analysis one uses, there is no question that the US is characterized by spatial inequalities.

\section{Causes and Consequences}

The United States faces a serious problem of uneven economic development. Whether at a macro, meso, or micro level, regions, states, counties, MSAs, and even areas such as different communities experience variations in income, unemployment, poverty, and other measures used to calculate or signify uneven development. The question now is why? 
$\mathrm{Wu}$ and Gopinath argue that the three classic variables that explain disparate development and they are natural amenities, infrastructure, and remoteness all affect economic development [59]. They conclude that of the three, remoteness is the most significant. Remoteness is the primary cause of spatial disparities in economic development across counties in the United States. It accounts for 76\%, $85 \%$, and $87 \%$ of the predicted differences in average wage, employment density, and land development density between the top and bottom 20\% of counties, respectively. Natural amenities make a large contribution to spatial variations in housing prices, accounting for 37\% of the predicted difference between the average median housing prices for the top 20\% of high housing-price counties and the bottom $20 \%$ of low-housing-price counties (405).

Remoteness is an important but not unsurprising factor for several reasons. Remoteness refers to distance from suppliers or customer markets and with there being transportation costs to move good or services, remoteness may implicate energy and other costs that drive-up development costs. Central place theory would argue that the placement or location of businesses is situated in places centrally proximate to customers and that it takes a specific density of population to create sufficient demand for products. Even those this type of theory is best suited for direct to customer products such as grocery stores, even manufacturing or other types of business to business (B2B) entities may find that it does not make sense to be in a remote location distant from other firms.

Second, remoteness might refer to places lacking suitable workforces or amenities to attract the types of workers or employers desired for a particular industry. This observation is consistent with many theories of business location decisions which see workforce issues (employee skills and compensation) as perhaps one of the main factors influencing where companies chose to locate. While certainly areas with less development often have lower wages, they too often have workers with less education or skill sets and therefore are unable to attract certain types of employers. Additionally, because areas undeveloped often are in areas lacking certain amenities such as cultural or other attractions, that may contribute to an inability of an area to keep or attract employees and therefore that makes it hard to encourage business development.

Third, remoteness might refer to a lack of similar businesses in an area. Michael Porter has described what is called a cluster theory of development [48, 49]. Clusters are groupings of similar industries located near one another. These clusters form because companies share similarly trained workforces, or because there are efficiencies of collaboration and learning. In effect, similarly related companies want to locate near one another. The most famous example in the US is Silicon Valley in California. The concept of cluster development is important because it points to reasons why some types of businesses want to be located near one another, or why investment tends to cluster in certain areas. It would be difficult simply to tell some businesses to move and invest in a specific area when it would not make much sense to be so distant from other businesses that are related to it. 
Overall, the remoteness provides a major clue to uneven development in the USA. But there are other factors that may important too. For example, historical patterns or legacies can explain uneven development. Krugman [30, 31], Acemoglu et al. [1], (Kim [28], and Mitchner and McLean [42] all locate North-South uneven economic development back to colonial America. Specifically, the latter trace the patterns back to slavery and the political institutions that created and sustained it until the US Civil War. These institutions, as Moore argued, sustained a slave economy that was slow to industrialize compared to the North and then the industrial capacity that the south had was destroyed during the Civil War [43]. Post-Civil War and even to this day the South developed with first sharecropper or near slave labor, and then eventually operated in an anti-union economy that organized around in-expensive, low technology, extractive work and businesses that persist to influence regional differences in the South to this day.

Finally, remoteness, as noted above, is closely connected to patterns in the US where one finds differentials in education, income, and poverty levels, for example. Whether it is a lack of education causes poverty and therefore uneven development, or the reverse, is difficult to determine because of the problem of ascertaining the lines of causality here. It might also be the multicollinearity among many of the variables, making it nearly impossible to sort one out as the cause. Yet as the next section points out, at least in the United States, the causes of uneven development are treated through a variety of strategies, the dominant two of which are economic incentives to encourage investment and the other is to provide worker training.

\section{Solutions}

One can describe uneven economic development as a market failure. In the US, government intervention may be called upon to address this problem. But formulating a viable policy response to uneven economic development first means properly identifying the cause or causes of uneven economic development. As noted above, there is no consensus on the causes. Classical theory sees the causes in variations among natural amenities, infrastructure, and remoteness. Other theories locate it in racism and even in the logic of capitalism itself. Additionally, there may be no one cause and instead multiple problems causing spatial economic inequality. But even acknowledging all this, the US has not made uneven economic development a major policy issue. At best, US economic policy vacillates between helping individuals versus helping regions, with a mixture of the two being employed. The former involves social welfare programs. These programs will not be discussed in this article.

For the most part solutions to address uneven economic development involve public tax breaks to encourage private business development or workforce training programs. In addition, some programs aim at worker education or training and infrastructure investments. Unfortunately, there seems to be little evidence that 
any of these policies or approaches has had much success in addressing uneven economic development.

One of the most frequently employed techniques in the United States to offset uneven economic development and encourage business investment is the use of tax breaks [51]. At the core of this belief is the idea that businesses make decisions about where to locate a facility based primarily, or perhaps even exclusively, upon taxes. Because of this belief, state and local governments have engaged in dramatic tax wars against one another to lure businesses to their community. What do we know about the impact of taxes upon business relocation decisions?

The literature is clear - tax breaks to encourage economic relocation are economically inefficient and wasteful. Hundreds of studies, including a bevy of them cataloged in State Tax Notes [55] reach this conclusion [3, 5, 12]. Michael Kieschnick [21] reviews numerous studies and methodologies examining the role of tax incentives on business location decisions. He concludes: "Even though there were considerable variations in the specific questions asked, the types of firms in the sample, and the areas in the country, taxes and financial inducements were consistently ranked in the bottom one-fifth or one-tenth of factors mentioned by respondents" (53). According to Michael Wasylenko [55] in his State Tax Notes survey of the economic literature and studies on the impact of taxes on business location decisions:

Two recent literature reviews ...find little evidence that the level of state and local taxation figures prominently in business location decisions. Lynch, in particular, notes that there is no evidence that state and local tax cuts, when paid for by reducing public services, stimulate economic activity or create jobs. Moreover, state and local tax incentives and financial inducements are not the only or even the primary influences on business location decisions. (1889)

Still other studies reach a similar conclusion. Roger Schmenner [50] notes how economists see taxes as having minimal impact on business location decisions, even though economic development practitioners and elected officials disregard his evidence. Bartik [5] reviewed 84 econometric studies undertaken since 1979 examining the role of tax incentives, generally finding that that taxes were inelastic - that is, relative changes in taxes across regions had little impact on location decisions.

Kieschnick [21] updates his earlier research and that by Bartik [5]. He performs a meta-regression analysis that examines the empirical results found in other studies. In effect, he combines the results from numerous previous studies on tax incentives, controlling for some inconsistencies in methodologies. Kieschnick concludes by stating that his results generally confirm Bartik's results.

When businesses are surveyed regarding factors important to their economic [re]location, taxes often come in way behind proximity to markets, suppliers, and the quality of the labor force [21,55]. Quality of life and the arts are also critical factors driving economic development [40]. None of this should come as a surprise. Many of these other factors occupy a larger percentage of a business' 
budget than do taxes, and all of them are far more critical to the long-term success of a business than are taxes.

When pressed, businesses will admit to this in public. For example, nearly $62 \%$ of those interviewed in a California study on hiring tax credits indicated that they had never or rarely affected their decision to hire individuals [10]. In the same study, nearly half of those interviewed stated that tax incentives for relocation did not affect their decisions $[10,17]$. Overall, the economic development literature states that tax incentives and levels of taxation are not major determinants of relocation, but instead might have some marginal influence when there is some tax elasticity and where the incidence is significant compared to other contiguous jurisdictions.

The argument here is not that taxes do not matter. Instead they matter but at a lower order or in more subtle ways than chambers of commerce types of arguments would suggest. First, when decisions regarding location are being made, other factors rank higher, such as labor costs or access to markets and suppliers. This is what businesses will first consider when making more macro or first cut decisions regarding where to locate. Once these major factors are considered then taxes become a secondary or tertiary level factor to narrow down more specific locations or jurisdictions in which to settle. At this point the question is perhaps settling within a specific city or a nearby one. Wasylenko makes this point about the marginal role of taxes at a more meso or micro level when he concludes that "This review of the literature suggests that taxes have a small, statistically significant effect on interregional location behavior" [55]. Once other factors are considered, it is here then that taxes may be a factor to determine or finalize a location choice. This makes sense. Labor for example constitutes a much greater percentage of doing business than do many other expenses. This means wages and workforce quality might be more significant factors in affecting business location decisions than are other variables.

Thus, when a business adds up all the costs and factors affecting where it should do business there may be only a handful of locations that make sense of a business to relocate to. Here is the point where businesses then pit communities against one another (LeRoy 2005). It is like the classic prisoners' dilemma. If two accomplices are separately questioned by the police, the best scenario would be for both to remain silent. If that were to occur perhaps both walk free. If one talks and confesses he goes free or gets a lesser sentence and the other gets a worse sentence. If both confess they both go to jail. No community wants to be the one taking the economic high ground and not do something. Moreover, no public official wants to look passive as neighbor rolls out the tax red carpet for a business. Thus, bidding war ensues and businesses are only too happy to encourage and take advantage of it [35].

But communities cannot resist the temptation to act, even if they conclude that it is wrong; instead political considerations often intrude into economic development decisions [39: 257-259]. Consider two recent studies. The first study entitled 
An Evaluation of the Keystone Opportunity Zone (KOZ) Program was prepared for the Pennsylvania Legislative Budget and Finance Committee in 2007 [18]. The report examined the role of tax incentives for individuals and businesses in the creation of special economic regions (enterprise zones) to induce economic development. While much of the report criticized inadequate data and recordkeeping that complicated accountability and appropriate analysis, it also noted that many of the claims about job creation and capital investment by the private sector were vastly overstated. The report concluded: "On an individual project basis, numerous $\mathrm{KOZ}$ projects appear to be working as intended and are rated as 'success stories,' although KOZ status alone is generally not the sole contributing factor in a business' decision to locate or relocate in a KOZ" (S-8). What the Pennsylvania report found was that claims about the efficacy and impact of tax cuts alone as a major factor encouraging business location decisions were exaggerated. They might have had some impact but it was more muted than its supporters contended.

A second study entitled Money for Something: Job Creation and Job Quality Standards in State Economic Development Subsidy Programs was prepared for the Good Jobs First organization in 2011 by Philip Mattera and three other authors [41]. They examined 238 state economic development programs across the 50 states and the District of Columbia. The analysis looked at a range of economic incentives that included tax cuts, subsidies, tax incentives, loans, and several other inducements. It is arguably one of, if not, the single most comprehensive examination of state-level economic development tools to date.

The authors document $\$ 70$ billion annually for economic development, with $\$ 11$ billion deployed in terms of a variety of tax incentives or programs as noted above [41: i]. Significant variation among state programs is noted, with only four states giving $\mathrm{B}$ or better grades in terms of how the programs are administered in terms of documenting results or making sure that the money is spent on jobs with good pay and health care coverage. Over half of the states earned grades of C- or worse. What the authors of the study found, as was like that with the Pennsylvania study, were that data gathering was often poor, performance exaggerated, and proof of real efficacy of the incentives questionable. But beyond these points, the authors describe how the types of jobs created - in terms of wages and benefits - often were poor. Thus, even if jobs or economic development occurred because of the incentive programs offered, the impact in terms of quality jobs was debatable. As the authors state in their executive summary:

At a time when unemployment remains high and states and cities are spending an estimated $\$ 70$ billion a year in the name of economic development, taxpayers are right to ask if such expenditures are creating a substantial number of good jobs. An analysis of major state economic development programs finds that many subsidy programs require little if any job creation. Fewer than half provide any kind of wage standard for the workers at subsidized companies, and fewer than a fourth require any sort of healthcare coverage [41:i]. 
The Good Jobs First argument is slightly different from the argument asserting that taxes are not a significant factor in economic development decisions. Yes, this assertion is implied in their report. With 238 programs in place across the country, the collective net effect of them is to cancel one another out. But the authors shift gears to question also about what types of jobs are being produced with taxes. They find that good jobs - those with living wages and benefits - are often wanting. Even if relocation occurred because of the tax incentives, the type of jobs and economic development that is produced is not very good.

Enterprise zones are a second and related way to encourage business investment. In the United States, they were developed as an economic development tool to revitalize depressed areas that were lacking in investment or job production. Often these areas were urban communities which, since the Model Cities programs of the 1960s, had been the focus of redevelopment. These were communities which some scholars had seen as creating cultures of poverty or were areas where work and jobs had disappeared $[57,58]$. Unfortunately, Model Cities did not work, or at least was perceived not to working or was abandoned in the Nixon administration, and instead replaced by the Community Development Block Grant Program and Urban Development Assistance Grants. But by the 1980s even these programs were not viewed favorably and during the Reagan Administration enterprise zones became a popular idea for economic development. These zones came to be development tools not just for urban cores, but for any depressed community needing an influx of capital investment.

Much of the logic of enterprise zones relies upon the assumptions of using tax abatements as incentives for business relocations or development or to encourage employment decisions. But in the case of enterprise zones, there is an identified geographic region that is deemed to be economically disadvantaged or needing special help. Within this zone, a state or local government would provide financial incentives, such as abated or reduced income, property, sales, or other types of taxes. In some cases, a region would be eligible for all the above. These tax incentives, along with perhaps infrastructure assistance, are supposed to induce businesses to relocate into the enterprise zone, and thereby bring with it jobs and all the benefits associated with their move.

While elegant in theory, how have enterprise zones worked? Bottom line: They are generally a cost ineffective failure in encouraging economic development and in producing meaningful employment opportunities. As summarized by Peters and Fischer:

Enterprise zone incentive programs do not seem to provide enough benefit to firms to materially alter their investment and locational habits; as a result, they do not induce much, if any new growth. Moreover, although enterprise zones are justified by politicians and academics alike as helping economically disadvantaged areas, zones do not appear to provide much in the way of employment opportunities to zone inhabitants. Furthermore, they tend to be very costly for government [44: 128]. 
Enterprise zones suffer from three defects. First, the financial benefits (tax abatements) are too little to induce relocation decisions. Second, the jobs they produce are not meaningful or are too costly given the public investments. Third, the overall programs are costly. Add to these three a fourth criticism: Enterprise zones merely move investment from one community to another at public expense, thereby creating no new economic gains while at the same time subsidizing relocation decisions that probably would have already occurred.

The logic of enterprise zones rests upon the same premises as the overall strategy of using taxes as a driver to induce development or relocation. This means enterprise zones are subject to the same criticisms as were described earlier in the chapter when it comes to taxes as a factor affecting business investment decisions. To repeat, as Bartik [5], Wasylenko [55], and others have shown, taxes are far down on the list of factors that influence economic location decisions. They are far less important than the quality of the workforce, access to supplies and markets, and a host of other factors. Thus, for taxes to be a major factor to induce relocation they would have to be of such magnitude beyond what any government offers.

Second the job production associated with enterprise zones is spotty at best. One study in California found, for example, that nearly half of the businesses involved in an enterprise zone program stated that the tax credits had little impact on their decisions to hire individuals [10]. A 2009 report from the Public Policy Institute of California found that enterprise zones had "no statistically significant effect on job creation" [10]. Even a 2001 HUD study on the federal Empowerment Zones and Enterprise Communities Program could not substantiate that the job growth in these areas was statistically better from the areas outside them during the hot economic binge of the 1990s [20]. The quality and cost of the jobs produced were also of concern in the report on these zones. The Pennsylvania Legislative Budget and Finance Committee's An Evaluation of the Keystone Opportunity Zone (KOZ) Program (2007) reported that "KOZ Program had resulted in the creation of 63,966 new jobs and the retention of over 48,158 jobs since the program began in 1999" (S-3). The report, once it dug into the claims, found that "KOZ jobs data was substantially overstated and not supportable" (S-3).

Overall several studies, such as by Boarnet et al. [7], Greenbaum and Engberg [13], and Bondonio and Engberg [8] reach similar conclusions: job and economic growth were not necessarily enhanced by enterprise zones. Even beyond their use for enterprise zones, tax breaks often fail to create the conditions for companies to hire individuals. For example, Berenson [6] reported that even with the billions of dollars in tax breaks given to drug companies, those incentives failed to yield the jobs promised.

In addition to tax cuts another approach used has involved workforce training or education training programs. Here the focus would be to provide education or skills training to workers. There is a significant body of literature that correlates worker productivity and wages to education. Business location studies, as noted above, 
are influenced by workforce skills. The conclusion here would be that providing more education and job training skills in economically undeveloped area would perhaps then induce more businesses to invest in an area. Education thus would offset regional economic imbalances.

There are at least four reasons why workforce investments have not succeeded in offsetting regional disparities. First, the primary focus of workforce development has had less of a geographic and more of an individual strategy. By that, while educational programs may be offered in a specific locality, the programs are directed to individuals who often take that training and emigrate to a different location or region. Workforce training and education are mobile and the benefits individual and they travel with individuals.

Second, the research suggests that many of the workforce training programs have produced mixed results. Basic primary and secondary education programs do help in improving worker skills, but studies of retraining programs raise questions regarding their efficacy. In some cases, they improve wages for some populations but their overall ability to transform the economic advantages of a region are in dispute.

Third, Holzer has indicated that the amount of money available for workforce training has gone down dramatically since the 1960s and 1970s [19]. There is simply too little invested in such programs now to make a difference. This decrease in public investment reinforces the point made above that addressing regional disparities is not a major policy issue in the United States.

Given the little investment made in workforce development it is not clear that it is sufficient to offset other factors that may cause regional disparities. For example, some regionals still enjoy advantages in natural or artificial amenities, or some regions or places may still be too remote. These factors may still make it too costly or not profitable enough to invest in a specific region. Thus, it may be however much is invested in worker training or education it may not benefit the region because workers move or because this investment cannot offset other variables that produce regional differences.

A third traditional strategy to addressing uneven economic development is through infrastructure investments. Such investments would be undertaken to upgrade roads or bridges in some areas, perhaps also investing in programs to address some of the problems related to remoteness. While the American Civil Engineering society has noted the deficiencies in infrastructure investment in the United States [2], the focus of their concern has been on maintenance of existing dilapidated roads and bridges and less if at all on investments in remote communities to offset economic disadvantages. Moreover, while money will be invested in infrastructure projects to link expanding suburban communities to the rest of a region, or in urban areas slated for redevelopment, there is no overall national, state, or local investment strategy that uses infrastructure as an explicit tool to offset uneven development. At best, some states, such as Minnesota, have 
sought to increase investments in Internet or broadband access to offset a digital divide across parts of the United States, but again there is no consensus or strategic policy to do this as a specific strategy to address uneven economic development.

\section{Conclusions}

The United States is like many if not every country in the world in that it experiences uneven economic development. There are many reasons for this spatial pattern. Classical theory would describe regions as varying in natural amenities, infrastructure, and remoteness, but other theories can also point to factors such as education and historical forces as contributing if not primary causes of uneven development. While the US has sought to address some aspects of uneven development, it either has not done so in a place-based (as opposed to an individualbased strategy), or with a consistent and intentional strategy. Instead, the problem of uneven development has either be explicitly ignored by US policy makers, or left as a problem for the market place to solve.

If any lessons can be taken from the US and applied elsewhere to countries such as the Russian Federation, there are three. The first that uneven development may be a problem which is impossible to eliminate. Some regions may be so remote or lacking in amenities that they will always lag in terms of development compared to other regions. Income or business subsidies may offset the worst of the problems, but they may not be sufficient to actually addressing what appears to be a structural problem. The second is that there does not appear to be any easy or simple solution to the problem of uneven development. There is no one strategy to addressing the problem, with perhaps a multi-pronged approach necessary to address the many factors that have caused a region to lag economically. Finally, if a country or government does wish to address uneven development then it needs to develop a strategy and investment policy, simply assuming that the free market will fix the problem is not a sufficient strategy.

(C) Schultz D., 2017

\section{REFERENCES}

[1] Acemoglu, Daron, Simon Johnson, and James A. Robinson. 2001. A The Colonial Origins of Comparative Development: An Empirical Investigation.@American Economic Review. 91: 1369-1401.

[2] American Civil Engineering Association. 2017. Infrastructure Report Card. URL: http:// www.infrastructurereportcard.org/ (site last visited on April 15, 2017).

[3] Anderson, John E. and Robert W. Wassmer. 2000. Bidding for Business: The Efficacy of Local Economic Development Incentives in a Metropolitan Area. Kalamazoo, MI: W.E. Upjohn Institute for Employment Research.

[4] Anon. 2016. ARich Province, Poor Province, @ Economist. October 1, pp. 41-42. 
[5] Bartik, Timothy J. 1991. Who Benefits from State and Local Economic Development Policies? Kalamazoo, MI: W.E. Upjohn Institute for Employment Research.

[6] Berenson, Alex. 2007. "Tax Breaks Used by Drug Makers Failed to Add Jobs as Advertised." New York Times (July 24), A1.

[7] Boarnet, John, David A. Jaeger, and William T. Bogart. 1996. "Enterprise Zones and Employment: Evidence from New Jersey." Journal of Urban Economics, vol. 40, no. 2, pp. 198-215.

[8] Bondonio, Daniele, and John Engberg. 2000. "Enterprise Zones and Local Employment: Evidence from the States' Programs," Regional Science \& Urban Economics, Vol. 30, No. 5, pp. 519-549.

[9] Braudel, Fernand. 1979. Civilization and Capitalism, 3 vols. NY: Harper \& Row.

[10] California Budget Project. 2006. "New Study Overstates the Effectiveness of Enterprise Zones." Budget Brief (August).

[11] Engberg, J., and R. Greenbaum. 1999. "State enterprise zones and local housing markets," Journal of Housing Research 10: 163-87.

[12] Fisher, Peter S. and Alan Peters. 1997 "Tax and Spending Incentives and Enterprise Zones." The Effects or State and Local Public Policies on Economic Development Symposium, New England Economic Review (March/April), pp. 109-30.

[13] Greenbaum, Robert, and John Engberg. 2004. "The Impact of State Enterprise Zones on Urban Manufacturing Establishments," Journal of Policy Analysis and Management, Vol. 23, No. 2, pp. 315-339.

[14] Hanley, Caroline. 2011. International Journal of Sociology, vol. 40, no. 4, Winter 2010-2011, pp. 6-30.

[15] Harris, Donald J. 2007. A Uneven Development.@ The New Palgrave Dictionary of Economics, 2nd edition, London: Macmillan.

[16] Harvey, David. 2007. A Brief History of Neoliberalism. New York: Oxford University Press.

[17] Hissong, Rod. 2003. "The Efficacy of Local Economic Development Incentives." In Sammis B. White, Richard D. Bingham, and Edward W. Hill (eds), Financing Economic Development in the 21st Century. Armonk, NY: M.E. Sharpe, pp. 131-144.

[18] Holoviak, Paula A. and Damian Carabello. 2008. An Evaluation of the Keystone Opportunity Zone (KOZ) and Keystone Opportunity Expansion Zone (KOEZ) Programs in Rural Pennsylvania. URL: http://www.rural.palegislature.us/KOZ2008.pdf (Site last visited on April 16, 2017).

[19] Holzer, Harry. 2011. A Very Uneven Road: US Labor Markets in the Past 30 Years. URL: https://s4.ad.brown.edu/projects/diversity/Data/Report/report03082012.pdf (site last visited on April 16, 2017).

[20] Housing and Urban Development. 2001. Interim Assessment of Empowerment Zones and Enterprise Communities (EC/EZ) Program: A Progress Report. Washington, DC: Department of Housing and Urban Development.

[21] Jargowsky, Paul. "Ghetto Poverty among Blacks in the 1980s," Journal of Policy Analysis and Management 13 (Winter): 288-310.

[22] Kieschnick, Michael. 1995. "The Effect of State and Local Taxes on Economic Development: A Meta-analysis." URL: http://www.thefreelibrary.com/The+effect+of+sta te+and+local+taxes+on+economic+development\%3a+a...-a017478992 (Site last visited June 12, 2012). 
[23] Kim, Sukkoo. 1995. Expansion of Markets and the Geographic Distribution of Economic Activities: The Trends in U.S. Regional Manufacturing Structure, 1860-1987. Quarterly Journal of Economics 110 (4): 881-908.

[24] Kim, Sukkoo. 1999. Regions, Resources and Economic Geography: The Sources of U.S. Regional Comparative Advantage, 1880B1987.@Regional Science and Urban Economics 29: $1-32$.

[25] Kim, Sukkoo. 2000. Urban Development in the United States, 1690-1990. Southern Economic Journal 66: 855-80.

[26] Kim, Sukkoo. 2006. Division of Labor and the Rise of Cities: Evidence from U.S. Industrialization, 1850-1880. Journal of Economic Geography 6: 469-91.

[27] Kim, Sukkoo. 2007 Changes in the Nature of Urban Spatial Structures in the United States, 1890-2000. Journal of Regional Science 47: 273-87.

[28] Kim, Sukkoo. 1998. Economic Integration and Convergence: U.S. Regions, 1840-1990. Journal of Economic History 58: 659-83.

[29] Kim, Sukoo. 2008. Spatial Inequality and Economic Development: Theories, Facts, and Policies. Washington, D.C. The World Bank.

[30] Kolko, Jed and David Neumark. 2009. Do California's Enterprise Zones Create Jobs? San Francisco, CA: Public Policy Institute of California.

[31] Krugman, Paul. 1991. Increasing Returns and Economic Geography. Journal of Political Economy 99: 483-99.

[32] Krugman, Paul. 1991. Geography and Trade. Cambridge: MIT Press.

[33] Kucheva, Yana Andreeva. 2011. Subsidized Housing and the Concentration of Poverty, 1977-2008: A Comparison between Eight US Cities Los Angeles: California Center for Population Research.

[34] Kuznets, S. 1966. Modern Economic Growth, Rate, Structure, and Spread. New Haven: Yale University Press.

[35] Kyrylych, Khrystyna. 2006. Problem of Uneven Economic Development of the World Economy: Essence and Causes. Intelektin Ekonomika. Vol. 7, No. 3(17), pp. 344-354.

[36] LeRoy, Greg. 2005. The Great American Jobs Scam: Corporate Tax Dodging and the Myth of Job Creation. San Francisco: Berrett-Koehler.

[37] Lichter, Daniel T., and Kenneth Johnson. 2007. Concentrated poverty in rural areas: The Changing Spatial Concentration of America $=$ s Rural Poor Population, Rural Sociology 72(3), pp. 331-358.

[38] Lichter, Daniel T., Domenico Parisi, and Michael C. Taquino. 2012. The Geography of Exclusion: Race, Segregation, and Concentrated Poverty, Social Problems, Vol. 59, Issue 3, pp. 364-388.

[39] Lobao, Linda M. Gregory Hooks \& Ann R. Tickamyer. 2007. Advancing the Sociology of Spatial Inequality, in The Sociology of Spatial Inequality 1-3, Linda M. Lobao et al. eds., SUNY Press.

[40] Malizia, Emil E. and Edward J. Feser. 1999. Understanding Local Economic Development. New Brunswick, NJ: Center for Urban Policy Research.

[41] Markusen, Ann and Amanda Johnson. 2006. Artists' Centers: Evolution and Impact on Careers, Neighborhoods, and Economies. Minneapolis, MN: Project on Regional and Industrial Economics, University of Minnesota: Part I.

[42] Mattera, Phillip, et al. 2011. Money for Something: Job Creation and Job Quality Standards in State Economic Development Subsidy Programs. URL: http://www.goodjobsfirst.org/ moneyforsomething (Site last visited on April 15, 2017). 
[43] Mitchener, Kris, and Ian McLean. 2003. AThe Productivity of U.S. States Since 1880. Journal of Economic Growth 8: 73-114.

[44] Moore, Barrington, Jr. 1966. Social Origins of Dictatorship and Democracy: Lord and Peasant in the Making of the Modern World. Boston: Beacon Press.

[45] Peters, Alan and Peter Fisher. 2003. "Enterprise Zones: How Effective Are They?" In Sammis B. White, Richard D. Bingham, and Edward W. Hill (eds), Financing Economic Development in the 21st Century. Armonk, NY: M.E. Sharpe, pp. 113-130.

[46] Peters, David J. 2012. AIncome Inequality across Micro and Meso Geographic Scales in the Midwestern United States, 1979-2009, Rural Sociology 77(2), pp. 171-202.

[47] Piketty, Thomas. 2014. Capital in the Twenty-First Century. Cambridge, MA: Belknap Press.

[48] Plant, Raymond. 2009. The Neo-Liberal State. NY: Oxford University Press.

[49] Porter, Michael. 2000. "Location, Competition, and Economic Development: Local Clusters in a Global Economy," Economic Development Quarterly, vol 14, no.1, pp. 15-34.

[50] Porter, M. E. 1998. "Clusters and the new economics of competition," Harvard Business Review, Nov/Dec98, Vol. 76 Issue 6, p. 77.

[51] Schmenner, Roger W. 1982. Making Business Location Decisions. Englewood Cliffs, NJ: Prentice-Hall.

[52] Snell, Ronald. 1998. A Review of State Economic Development Policy. Denver, CO: National Council of State Legislatures.

[53] Tiebout, Charles. 1956. "A Pure Theory of Local Expenditures". Journal of Political Economy. 64 (5): 416-424.

[54] Tomaskovic-Devey, Donald and Vincent J. Roscigno. 1997. Uneven Development and Local Inequality in the U.S. South: The Role of Outside Investment, Landed Elites, and Racial Dynamics. Sociological Forum, vol. 12, no. 4.

[55] Wallerstein, Immanuel. 1976. The Modern World System: Capitalist Agriculture and the Origins of the European World-Economy in the Sixteenth Century. New York: Academic Press.

[56] Wallerstein, Immanuel. 1979. The Capitalist World-Economy. NY: Cambridge University Press.

[57] Wasylenko, Michael. 1997. "Taxation and Economic Development: The State of the Economic Literature." State Tax Notes (June 23), pp. 1883-1895.

[58] White, Sammis B., Richard D. Bingham, and Edward W. Hill. 2003. Financing Economic Development in the 21 st Century. Armonk, NY: M.E. Sharpe.

[59] Wilson, William Julius. 1996. When Work Disappears: The World of the New Urban Poor New York: Alfred A. Knopf.

[60] Wilson, William Julius. 2009. The Political and Economic Forces Shaping Concentrated Poverty, Political Science Quarterly Volume 123 Number 4, pp. 555-571.

[61] Wu, JunJie, and Munisamy Gopinath. 2008. What Causes Spatial Variations in Economic Development in the United States?@ American Journal of Agricultural Economics. 90 (2) (May 2008): 392-408. 


\title{
РЕГИОНАЛЬНЫЕ ДИСПРОПОРЦИИ \\ В ЭКОНОМИЧЕСКОМ РАЗВИТИИ: ОПЫТ СОЕДИНЕННЫХ ШТАТОВ АМЕРИКИ
}

\author{
Дэвид Шультц
}

\author{
Университет Хэмлин \\ Сент Пол, Миннесота, США, 55105
}

\begin{abstract}
Экономическое развитие не является однородным в геополитическом аспекте. Есть географическая составляющая, которая оказывает сильное влияние на развитие в некоторых регионах мира и в разных частях страны, включая Российскую Федерацию, делая одни регионы более экономически развитыми, чем другие. В данной статье в качестве примера рассматривается неравномерное экономическое развитие в США. В частности, данная статья определяет, что понимается под неравномерностью развития, а также в статье описывается закономерность неравномерного развития в Соединенных Штатах. В статье также рассматриваются причины и последствия неравномерного развития и рассмотрены некоторые возможные решения выявленных проблем. Общий вывод заключается в том, что США испытывает значительное влияние географической составляющей на ее экономическое развитие. Кроме того, не до конца очевидно, насколько проводимая политика является успешной и действительно способствует ослаблению, замедлению или ликвидации неравномерности развития регионов страны.
\end{abstract}

Ключевые слова: неравномерность экономического развития; США; пространственное неравенство; бедность; неравенство доходов

\section{Сведения об авторах:}

Шультц Дэвид - профессор кафедры политических наук Университета Хэмлин (Миннесота, США), главный редактор журнала Public Affairs Education (JPAE).

E-mail:dschultz@hamline.edu 